\title{
MUCI positive cutaneous metastasis with transepidermal elimination from a breast carcinoma
}

This article was published in the following Dove Press journal:

International Medical Case Reports Journal

6 November 2013

Number of times this article has been viewed

\author{
Amalia Luna \\ Maria Emilia Merino \\ Cecilio G Alberdi \\ Martin C Abba \\ Amada Segal-Eiras \\ Maria Virginia Croce \\ Center of Basic and Applied \\ Immunological Research, Faculty of \\ Medical Sciences, National University \\ of La Plata, Argentina
}

\begin{abstract}
Breast cancer is the most common cause of cutaneous metastases from internal malignancies. Generally, the neoplastic cells are located in the dermis or hypodermis, while a finding of transepidermal elimination on cutaneous metastases is exceptional. In this report we present a patient with perforating cutaneous metastases from breast cancer with mucin 1 expression. Cutaneous, bone, lung, and hepatic lesions were detected two years after the diagnosis of the primary tumor.
\end{abstract}

Keywords: breast cancer, cutaneous metastasis, transepidermal elimination, MUC1

\section{Introduction}

Cutaneous metastases are defined as dermal or hypodermal neoplastic tissue that has no contiguity with the primary tumor. Skin metastases from internal neoplasms are an uncommon clinical finding with an overall incidence of $5.3 \%$ and the most common cause is breast cancer with an incidence of $23.9 \%{ }^{1}$

In general, skin metastases of breast cancer affect the dermis and histologically appear as malignant ductal epithelial cells in sheets, cords, glands, or are arranged in a diffuse infiltrate. ${ }^{2}$ The finding of transepidermal elimination on cutaneous metastases is exceptional and has only been reported in a few cases. ${ }^{3,4}$ Mehregan classified transepidermal elimination into three types, and the elimination of dermal tumor nests corresponds to type 3 which involves an active interaction between epidermis and dermal connective tissue. ${ }^{5}$ Although transepidermal elimination is the histological feature of the classical perforating disorders, it is also described in other cutaneous conditions and in tumors such as melanocytic nevus, ${ }^{6}$ eccrine poroma, ${ }^{7}$ malignant melanoma,${ }^{8}$ pilomatricoma,${ }^{9}$ and metastatic carcinoma. ${ }^{3,4}$ In this report we present a case of perforating cutaneous metastasis from breast cancer with mucin 1 (MUC1) expression.

\section{Case report}

In February 2010, a 48-year-old Argentine woman had undergone tumorectomy in her left breast with diagnosis of an invasive ductal carcinoma with low nuclear and histological differentiation grades; estrogen (ER) and progesterone (PR) receptors were negative and Her2/neu was positive. In September 2011, a mastectomy with immediate breast reconstruction was performed due to local tumor recurrence and the patient received systemic chemotherapy. In March 2012, she consulted because multiple skin nodules had appeared 3 months before. Lung, bone, and hepatic metastases were also detected.
Center of Basic and Applied Immunological Research, Faculty of Medical Sciences, National University of La Plata, Calle 60 and I20, 1900 La Plata, Argentina Tel +5422 I423 67II

Fax +5422I4258989

Email crocevir@hotmail.com how to request permission may be found at: http://www.dovepress.com/permissions.php 
Physical examination revealed an erythematous nodule that was $4 \mathrm{~cm}$ in diameter, polylobulated, and with ulcerated surface on the chest region. Multiple erythematous painful nodules from $5 \mathrm{~mm}$ to $2 \mathrm{~cm}$ were distributed on her chest and over the reconstructed breast (Figure 1).

A skin biopsy of one of the small lesions revealed skin metastasis from breast carcinoma (ER-PR-Her2/neu+). Histopathologically, tumor cell nests were seen in the dermis. By immunohistochemistry, MUC1 expression was studied and a strong reaction was found with a mixed pattern at the plasma membrane and in the cytoplasm (Figure 2). Some epidermal cells at the Malpighi stratum also showed cytoplasmic positive staining. Tumor cells in the papillary dermis appeared to penetrate through the epidermis, suggesting transepidermal elimination. The epidermis showed no signals of ulceration (Figure 3), and in some malignant cells, a MUC1 moderate reaction was found.

\section{Discussion}

Cutaneous metastases from breast carcinoma usually appear months to years after the diagnosis and treatment of the primary malignancy. ${ }^{10,11}$ The most common localizations are in the chest wall and abdomen, but they can also be found in the scalp and extremities. ${ }^{10}$ The clinical presentations vary over a wide range of different patterns. Nodules are the most common manifestation ( $80 \%)$, followed by telangiectatic carcinoma (11\%), erysipeloid carcinoma (3\%), "en cuirasse" carcinoma (3\%), alopecia neoplastica (2\%), and a zosteriform type $(0.8 \%){ }^{12}$ A diagnosis of cutaneous metastases is based on the clinical manifestations and the histopathologic study of the lesions.

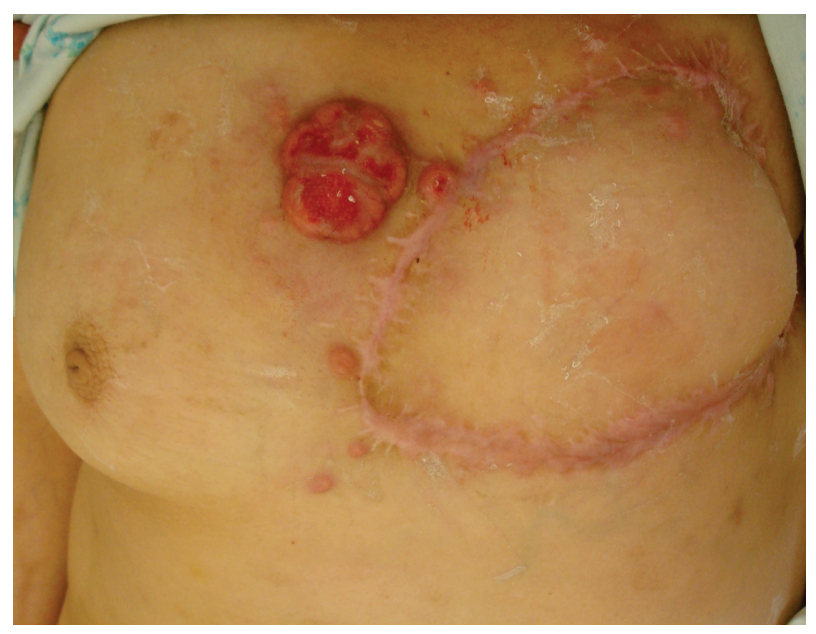

Figure I An ulcerated metastatic nodule on the chest region is observed. Note: Other metastatic lesions over the chest and reconstructed breast are also present.

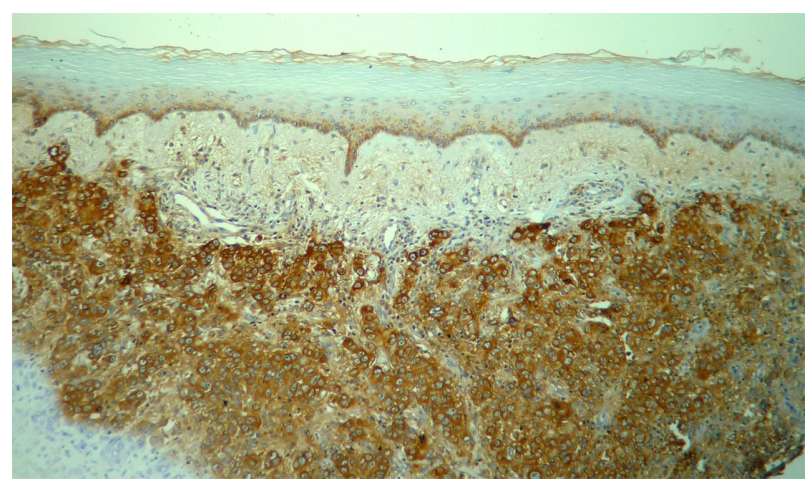

Figure 2 Microphotograph of immunoperoxidase staining of a metastatic cutaneous lesion of the patient.

Notes: Neoplastic cells in the dermis show a strong reaction with anti-mucin I monoclonal antibody (HMFGI monoclonal antibody) with a mixed pattern.

Histopathologically, cutaneous metastatic nodules show malignant cells in the dermis arranged in nests surrounded with desmoplastic stroma. ${ }^{2}$ In our patient, clinically, the skin lesions were nodules, but histologically, tumor cells were not restricted to dermal nests since they also showed perforation and transepidermal elimination.

Altered structures of the dermis and foreign material like neoplastic cells or external substances can be removed from the dermis by different mechanisms. Mehregan ${ }^{5}$ classified transepidermal elimination into three types which differ in the mechanism of removal. In type 1, nonmotile cells or small particles, which produce minimal or no dermal reaction, can be caught between keratinocytes and carried to the epidermis surface during corneocyte differentiation. In type 2, motile cells or microorganisms actively migrate into the epidermis and are subsequently eliminated with normal desquamation

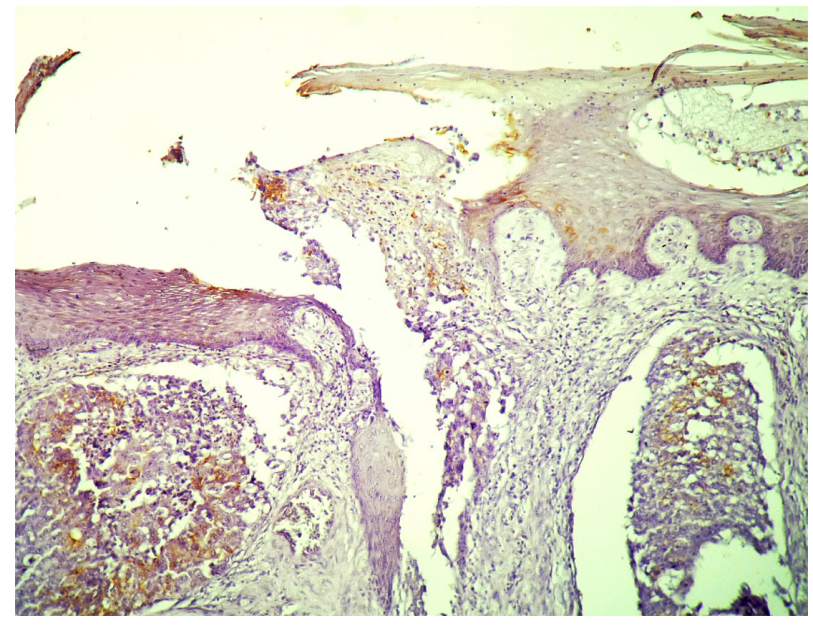

Figure 3 Breast cancer cutaneous metastasis.

Notes: Tumoral malignant cell nests passing through the epidermis are observed. Mucin I expression is found at the epidermal borders and at the tumor cells. The pattern of expression is cytoplasmic. 
similar to type 1 . Type 1 and type 2 are passive processes and have been termed "transmigration." Type 3 involves epithelial-dermal interaction with active elimination of the foreign material through the epidermis.

The phenomenon of transepidermal elimination occurs in certain dermatoses in which altered structures of the dermis and foreign substances induce an inflammatory response causing the release of collagenases, elastases, and proteases. This inflammatory response generates alteration of the matrix with necrosis and perforation, and can also stimulate pseudoepitheliomatous hyperplasia of the epidermis and subsequent formation of transepidermal perforating canals with elimination of the dermal material. ${ }^{4,5}$

In a case reported by Ohnishi et $\mathrm{al},{ }^{3}$ breast cancer cutaneous metastases with transepidermal elimination presented with epidermotropism of neoplastic cells and pagetoid spread, features that our patient did not show. On the other hand, Abbas et $\mathrm{al}^{4}$ published a case of perforating cutaneous metastasis from an ovarian carcinoma which showed malignant cells in the dermis and hypodermis with areas of transepidermal elimination without epidermotropism. Immunohistochemical staining of the tumor cells was positive for MUC1, as we report in our case.

Almost all breast cancer cells express $\mathrm{MUC}^{13-16}$ although benign breast neoplasms and normal breast cells express this mucin as well. ${ }^{17,18}$ It is considered that MUC1 nonapical expression, as well as its overexpression, are the hallmarks of MUC1 reactivity in breast cancer cells. ${ }^{19}$

Although contradictory results have been found between MUC1 expression and survival in breast cancer patients, more than $70 \%$ of studies on tumor samples have found that the presence of any MUC1 in the majority of tumor cells is associated with an improved prognosis. ${ }^{20}$ In relation to subcellular localization of MUC1, it has been observed that patients with tumors with the lineal (membrane) pattern have better survival. ${ }^{21-23}$ Rahn et $\mathrm{al}^{20}$ reported that aberrantly localized MUC1 in the tumor cell cytoplasm or nonapical membrane is associated with a worse prognosis. In a previous report, we found a significant decrease of MUC1 apical expression frequency according to histological as well as nuclear grade increment. In this sense, it is known that histological grade is an accurate predictor of tumor behavior. ${ }^{24}$ The presence of apical membrane staining would indicate that MUC1 targeting pathways are intact, and it has been associated with better prognosis that is possibly related to functional differentiation of the tumor. ${ }^{24}$ Rahn et $\mathrm{al}^{20}$ also found a significantly lower mean nuclear grade in tumors with high MUC1 expression $(50 \%)$. Coincidentally, in the primary tumor of our patient, a high nonapical MUC1 expression along with low nuclear and differentiation grades was observed.

MUC1 may alter the interaction between tumor cells and their environment, changing the composition. It has been observed that MUC1 cytoplasmic tail interacts with $\beta$-catenin through a similar motif to that found in E-cadherin and inhibits the formation of an E-cadherin- $\beta$-catenin complex, reducing cell-cell adhesion. ${ }^{19}$

Similar to Abbas et al, ${ }^{4}$ it is possible that in our case, the contributing factors to transepidermal elimination could be related to a tumor-dermis interaction in which the epidermis does not seem to be implicated. The physical effect by the expanding tumor and the inflammatory response are factors to be considered. Also, the possibility of a vascular compromise resulting in necrosis and ulceration of the epidermis as well as MUC1 expression may play a role.

\section{Disclosure}

The authors declare no conflict of interest.

\section{References}

1. Krathen RA, Orengo IF, Rosen T. Cutaneous metastasis: a meta-analysis of data. South Med J. 2003;96(2):164-167.

2. Hussein MR. Skin metastasis: a pathologist's perspective. J Cutan Pathol. 2010;37:e1-e20.

3. Ohnishi A, Yoshida Y, Hayashi K, Yamamoto O. Epidermotropic metastases with trans-epidermal elimination from breast carcinoma. Acta Derm Venereol. 2008;88(2):164-165.

4. Abbas O, Salem Z, Haddad F, Kibbi AG. Perforating cutaneous metastases from an ovarian adenocarcinoma. J Cutan Pathol. 2010;37(9):e53-e56.

5. Mehregan AH. Transepidermal elimination. In: Mali JW, editor. Current Problems in Dermatology. Basel: Karger; 1970;3:124-147.

6. Kantor GR, Wheeland RG. Transepidermal elimination of nevus cells. A possible mechanism of nevus involution. Arch Dermatol. 1987;123(10):1371-1374.

7. Arai K, Fujita H, Suzuki M, Iwasaki K. A case of eccrine poroma with multiple transepidermal elimination. J Dermatol. 1997;24: 539-542.

8. Goette DK. Transepidermal elimination in malignant melanoma. J Assoc Milit Dermatol. 1980;6:9.

9. Alli N, Gungor E, Artuz F. Perforating pilomatricoma. J Am Acad Dermatol. 1996;35(1):116-118.

10. Lookingbill DP, Spangler N, Helm KF. Cutaneous metastases in patients with metastatic carcinoma: a retrospective study of 4020 patients. J Am Acad Dermatol. 1993;29(2Pt1):228-236.

11. Nava G, Greer K, Patterson J, Lin KY. Metastatic cutaneous breast carcinoma: a case report and review of the literature. Can J Plast Surg. 2009; 17(1):25-27.

12. Mordenti C, Peris K, Concetta Fargnoli M, et al. Cutaneous metastatic breast carcinoma: a study of 164 patients. Acta Dermatoveneorol Alp Panonica Adriat. 2000;9:143-148.

13. Burchell J, Durbin H, Taylor-Papadimitriou J. Complexity of expression of antigenic determinants, recognized by monoclonal antibodies HMFG-1 and HMFG-2, in normal and malignant human mammary epithelial cells. J Immunol. 1983;131(1):508-513.

14. Gendler SJ, Spicer AP, Lalani EN, et al. Structure and biology of a carcinoma-associated mucin, MUC1. Am Rev Respir Dis. 1991; 144(3 Pt 2):S42-S47. 
15. Croce MV, Isla-Larrain MT, Rua CE, Rabassa ME, Gendler SJ, SegalEiras A. Patterns of MUC1 tissue expression defined by an anti-MUC1 cytoplasmic tail monoclonal antibody in breast cancer. $J$ Histochem Cytochem. 2003;51(6):781-788.

16. Croce MV, Isla-Larrain MT, Demichelis SO, Gori JR, Price MR, SegalEiras A. Tissue and serum MUC1 detection in breast cancer patients. Breast Cancer Res Treat. 2003;81(3):195-207.

17. Taylor-Papadimitriou J, Millis R, Burchell J, Nash R, Pang L, Gilbert J. Patterns of reaction of monoclonal antibodies HMFG-1 and -2 with benign breast tissues and breast carcinomas. J Exp Pathol. 1986;2(4):247-260.

18. Demichelis SO, Alberdi CG, Servi WJ, Isla-Larrain MT, Segal-Eiras A, Croce MV. Comparative immunohistochemical study of MUC1 and carbohydrate antigens in breast benign disease and normal mammary gland. Appl Immunohistochem Mol Morphol. 2010;18(1):41-50.

19. Gendler SJ. MUC1, the renaissance molecule. J Mammary Gland Biol Neoplasia. 2001;6(3):339-353.

20. Rahn JJ, Dabbagh L, Pasdar M, Hugh JC. The importance of MUC1 cellular localization in patients with breast carcinoma: an immunohistologic study of 71 patients and review of the literature. Cancer. 2001;91(11):1973-1982.
21. Ceriani RL, Chan CM, Baratta FS, Ozzello L, DeRosa CM, Habif DV. Levels of expression of breast epithelial mucin detected by monoclonal antibody BrE-3 in breast-cancer prognosis. Int J Cancer. 1992;51(3): 343-354.

22. Hayes DF, Mesa-Tejada R, Papsidero LD, et al. Prediction of prognosis in primary breast cancer by detection of a high molecular weight mucin-like antigen using monoclonal antibodies DF3, F36/22, and CU18: a Cancer and Leukemia Group B study. J Clin Oncol. 1991;9(7):1113-1123.

23. Wilkinson MJ, Howell A, Harris M, Taylor-Papadimitriou J, Swindell R, Sellwood RA. The prognostic significance of two epithelial membrane antigens expressed by human mammary carcinomas. Int $J$ Cancer. 1984;33(3):299-304.

24. Rakha EA, Reis-Filho JS, Baehner F, et al. Breast cancer prognostic classification in the molecular era: the role of histological grade. Breast Cancer Res. 2010;12(4):207.
International Medical Case Reports Journal

\section{Publish your work in this journal}

The International Medical Case Reports Journal is an international, peer-reviewed open-access journal publishing original case reports from all medical specialties. Previously unpublished medical posters are also accepted relating to any area of clinical or preclinical science. Submissions should not normally exceed 2,000 words or

\section{Dovepress}

4 published pages including figures, diagrams and references. The manuscript management system is completely online and includes a very quick and fair peer-review system, which is all easy to use. Visit $\mathrm{http}: / / \mathrm{www}$.dovepress.com/testimonials.php to read real quotes from published authors. 